Левченко А.В.

\title{
Аспекты личностной готовности современного мужчины к отцовству
}

Родительство является не только биологическим, но и биосоциальным и социокультурным явлением, его характеристики по-разному взаимодействуют между собой. Отношения родителей и ребенка зависят от их собственного пола и пола ребенка, возраста ребенка, конкретных социальных условий, традиций $[2,3]$, а также, мы предполагаем, от собственного опыта детства взрослого и его представлений об идеальных и реальных родителях. Воспитательное влияние примера родителей связано с моральным обликом отца и матери, общим у кладом семьи, обстановкой в родительском доме. Для ребёнка семья - это микросреда, общество, которое оказывает влияние на становление его личности. Особенное влияние на детей оказывает авторитет родителей [6]. Таким образом, именно в семье ребёнок получает первые сильные и яркие впечатления.

Кроме того, отцовство, родительство, материнство являются элементом репрезентативной культуры общества, закрепляющей данные образцы как должное, когда средства массовой информации выступают в качестве субъекта социального конструирования реальности. В результате, «медийная продукция стереотипизирует гендерные мифы общественного сознания и выдает их в качестве готовых моделей поведения или национальных архетипов, которые не только отражают существующие модели отцовство, но представляют собой прямые инструкции к действию» [8]. К примеру, современная рекламная продукция демонстрирует родительские образы, свойственные традиционной, патриархальной культуре, противопоставляя образу непрактичного, не способного у хаживать за ребенком отца образ умелой и практичной матери, подчеркивая существующие в обществе межполовые отношения, игнорируя тем самым декларируемое равноправное участие родителей в воспитании детей.

Действительности, участие отца в воспитании ребенка невозможно переоценить, оно необходимо для формирования полноценной личности, при условии четкого различения родительских ролей, оказывает положительное влияние на развитие детей. Психологическая подготовка мальчика к будущей роли отца обеспечивает его тесные эмоциональные контакты с собственным ребенком, повышает удовлетворенность своей отцовской ролью.

Формирование психологической готовности мужчины к отцовству начинается задолго до получения известия о беременности супруги. Внутренняя (психологическая) готовность к отцовству складывается на основе опыта, который демонстрировал отец мужчины: индивидуальный стиль отцовства является базисом для формирования личности ребенка, психологических особенностей, которые в дальнейшем будут определять стратегии поведения в различных жизненных 
ситуациях. В юношеском возрасте осуществляется выработка ценностей, ценностных ориентаций, жизненных планов, утверждается самостоятельность, что настраивает личность на поиск жизненного смысла, направленного на будущее. В зрелом возрасте происходит стабилизация всего жизненного у клада индивида и его личностных особенностей. Переход мужчины от холостяцкого образа жизни к семейному, период его подготовки к рождению детей психологи обоснованно считают кризисными этапами [7]. На пути к осознанному отцовству мужчина должен ответить на вопрос: насколько он готов к отцовству, что может дать своему ребенку, несмотря на все тяготы супружеской жизни, чем готов пожертвовать. У мение ответить на этот вопрос характеризует степень готовности женщин и мужчин стать родителями [9].

Для того, чтобы определить, каким отцом быть «мне самому», мужчина обращается к детскому опыту, полученному в собственной родительской семье. Модель отцовства, которую демонстрировал отец (другой значимый близкий мужчина) обеспечивает личность готовым образцом, объектом идентификации. Образ значимого другого становится эталоном, ориентирующим саморазвитие мужчины. Более того, исследователи Дж. Болен [1], К. Кенфилд [4] подтверждают, что непосредственно отцовство актуализирует неизжитые детские психологические проблемы, личностные конфликты. Поэтому, велика вероятность того, что молодой отец станет проецировать и переносить собственные детские переживания и обиды в свою «новую» семью. Если образ отца воспринимается сыном как положительный, ребенок стремится стать «таким как папа». В противном случае, когда воспитательный процесс со стороны отца сопровождался безразличием, физическими наказаниями, частым или постоянным отсутствием, повзрослев, молодой человек говорит: «Я таким никогда не буду!». И теперь негативный образ отца является меркой для сравнения, исходной точкой для движения к противоположному образу-идеалу (действие от противного).

Таким образом, можно заключить, что представление об отцовстве у мужчины складывается, во-первых, из его опыта, полученного до собственного отцовства, во-вторых, из ожиданий, связанных непосредственно с родительством. Опыт «до собственно отцовства» складывается из восприятия реальных взаимоотношений с отцом (или замещающим его лицом) - у своенные образцы поведения и реагирования. Также матери часто идентифицируют сына с отцом, иногда сравнение носит положительный, иногда и отрицательный характер («Ты совсем как твой папочка», «Ну, вылитый отец!»). Образ отца, не всегда достоверный, рисуют СМИ, кино- и литературные герои.

Исследование феноменологического пространства отцовства затрудняется целым рядом факторов. Во-первых, можно однозначно сказать, что картина отцовства для каждого мужчины уникальна и индивидуальна, т.к. складывается из аспектов отношений с собственным отцом, родительских взаимоотношений как трансляции модели семейного поведения. В связи с этим при исследовании личностных характеристик мужчин-отцов (будущих отцов) крайне важным оказывается 
наличие в анкете биографического блока, из которого становится ясным, проживал ли ребенок в семье с родным отцом, до какого возраста. Если отца не было рядом, был ли человек, который заменил отца, взяв на себя воспитательные функции (дедушка, отчим, крестный, дядя и пр.). Во-вторых, на формирование образа идеального отца в сознании молодого мужчины, безусловно, влияют стереотипы, существующие в современном обществе [5]. В-третьих, тема взаимоотношений с собственным отцом актуализирует прошлый опыт мужчины, который не всегда оценивается как положительный. В связи с этим, некоторые респонденты с нежеланием обсуждают данную тему, игнорируя некоторые блоки опросника, либо полностью отказываются от участия в исследовании. Перед исследователем встает задача подготовки испытуемого к работе с негативным опытом, нахождения способов проникновения к воспоминаниям о детско-родительских отношениях сквозь психологические защиты. Совокупность данных факторов затрудняет не только технический аспект сбора эмпирического материала, но и осложняет процесс классификации полученных данных.

\section{Литература}

1. Болен Джин Шинода. Боги в каждом мужчине. Архетипы, управляющие жизнью мужчин. Перевод Е. Мирошниченко. - М., 2005.

2. Борисенко Ю.В. Психология отцовства//Журнал практического психолога. - №1, 2007.

3. Евсеенкова Ю.В. Отцовство как психологический фактор развития личности. Диссертация канд.психол.наук. - Новосибирск, 2006.

4. Кенфилд Кен. Сердце отца. Как отцы могут изменить будущее своих детей. СанктПетербург - Киев, 2001.

5. Левченко А.В. Образ отца как эталон личности для молодого мужчины//Материалы IV Всероссийского съезда РПО «Психология - будущему России», Ростов-на-Дону, 18-21 сентября 2007.

6. Никандров Н.Д. Россия: социализация и воспитание на рубеже тысячелетий. Махачкала: Издательство «Юпитер», 2000. - 189 с.

7. Олифирович Н.И., Зинкевич-Куземкина Т.А., Велента Т.Ф. Психология семейных кризисов. - СПб.: 2006.

8. Рыбалко И.В. Трансформация отцовства в современной России. Автореферат диссертации. - Саратов, СГТУ, 2006.

9. Смирнова Е.Г. Феноменология родительства в молодых семьях//Психология зрелости и старения. - №1 (29). -2005. - С. $72-79$ 